\title{
Calling dan cinta pekerjaan sebagai faktor yang mempengaruhi keterikatan kerja anggota Polri
}

\author{
Aulia Aulia ${ }^{a, 1 *}$, Jarot Tri Adionob,2 \\ aFakultas Psikologi, Universitas Ahmad Dahlan, Yogyakarta \\ bPolda Metro Jaya, Jakarta \\ *1aulia@psy.uad.ac.id;2triadiono@hotmail.com \\ *Correspondent Author
}

Received: 06-10-2021

Revised: 08-11-2021

Accepted: 17-11-2021

\section{KAT A KUNCI}

calling;

cinta pekerjaan;

keterikatan kerja;

polisi

\section{KEYWORDS}

calling;

love of work;

work engagement;

police

\section{ABSTRAK}

Tuntutan tugas dan tingginya beban kerja anggota polisi bukanlah sesuatu yang dapat dipandang sebelah mata. Mengingat bahwa hal tersebut dapat berdampak pada tingginya tingkat stres dan berpotensi besar mempengaruhi performa anggota dalam bekerja, termasuk keterikatan dengan pekerjaan yang mereka lakukan. Oleh karena itu, melakukan kajian yang berhubungan dengan keterikatan kerja di dalam lingkup anggota Polri merupakan sesuatu yang penting, agar dapat diketahui faktor apa saja yang berkemungkinan memiliki pengaruh terhadap keterikatan kerja anggota, agar ke depan dapat menjadi alternatif rekomendasi bagi institusi terkait untuk terus dapat melakukan antisipasi dalam mempertahankan keterikatan kerja anggota Polri. Berdasarkan hal tersebut, penelitian ini bertujuan menguji secara empirik pengaruh calling dan cinta pekerjaan terhadap keterikatan kerja anggota Polri. Metode pada penelitian ini menggunakan pendekatan kuantitatif dengan desain crossectional study. Populasi pada penelitian ini adalah anggota polisi yang masih aktif bekerja dan memiliki masa kerja minimal satu tahun. Pengambilan sampel dilakukan dengan teknik purposive, dan untuk memenuhi karakteristik purposive tersebut maka penelitian ini menggunakan sampel anggota Polisi yang berada di bawah wilayah Polda Metro Jaya. Total sampel pada penelitian ini adalah sebanyak 430 anggota polisi. Metode pengambilan data pada penelitian ini menggunakan Utrecht Work Engagement Scale (UWES) yang telah dimodifikasi, skala calling, dan skala cinta pekerjaan. Teknik yang digunakan untuk pengolahan data pada penelitian ini adalah analisis regresi berganda. Berdasarkan hasil penelitian menunjukan perolehan $\mathrm{R}=0,644, \mathrm{~F}=151,449(\mathrm{p}<0,01)$, sehingga dapat disimpulkan bahwa secara simultan calling dan cinta pekerjaan memiliki pengaruh terhadap keterikatan kerja anggota polri.

\section{Calling and love of work as the factors affecting work engagement in Indonesian Police officers}

High demands for the task and the heavy workload on police officers cannot be underestimated. Considering that such burdens can impact a high level of stress and have significant potential to affect the officers' performance at work, including engagement with the work they occupy. Therefore, conducting a study related to work engagement within the scope of the Indonesian Police officers is something important, so it can be known what factors might bring an influence on the work 
engagement of the officers, for in the future, it can be an alternative recommendation toward related institutions to anticipate maintaining the work engagement of police officers continuously. Thus, this study aims to empirically examine the effect of calling and love of work on Indonesian Police officers' work engagement. The method in this study used a quantitative approach with a cross-sectional study design. The population in this study are police officers who are still actively working with a minimum one year of service period. The study applied a purposive sampling technique, and to meet these purposive characteristics, this study used samples from police officers in the Polda Metro Jaya area. The total sample in this study was 430 police officers. The data collection method in this study used the modified Utrecht Work Engagement Scale (UWES), the calling scale, and the love of work scale. The technique used for data processing in this study is multiple regression analysis. Based on the research results, the acquisition of $R=$ $0.644, F=151.449$ ( $p<0.01)$, so it can be concluded that simultaneously calling and love of work influence the work engagement of Indonesian police officers.

This is an open-access article under the CC-BY-SA license.

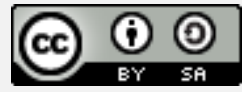

\section{Pendahuluan}

Kepolisian merupakan salah satu institusi yang memiliki peranan penting di Indonesia. Peranan tersebut khususnya dalam proses penegakan hukum, termasuk pemberian pelayanan kepada masyarakat umum dalam rangka pencegahan kejahatan dan perlindungan kepada masyarakat. Sesuai dengan ketentuan yang mengatur fungsi kepolisian seperti yang termaktub dalam Pasal 30 ayat (4) UUD 1945, Pasal 6 ayat (1) Ketetapan MPR RI No.VII/MPR/2000, dan Pasal 5 ayat (1) UU No.2 Tahun 2002 (dalam Guntur, 2017) disebutkan bahwa Kepolisian Negara Republik Indonesia merupakan alat negara yang menjalankan salah satu fungsi pemerintahan, terutama di bidang pemeliharaan keamanan dan ketertiban masyarakat melalui pemberian perlindungan, pengayoman dan pelayanan kepada masyarakat serta penegakan hukum.

Konsekuensi dari tingginya tugas pokok yang diemban oleh anggota polisi tidak hanya menuntut anggota bekerja selama delapan jam perhari, melainkan sebanyak 1x24 jam. Artinya, setiap anggota polisi dituntut untuk selalu siap siaga memenuhi panggilan tugas, bilamana sewaktu-waktu negara membutuhkan. Sementara secara psikologis tuntutan tugas dan beban kerja yang ditanggung oleh anggota polisi berpotensi besar untuk mempengaruhi keterikatan anggota terhadap pekerjaannya. Asumsi tersebut sesuai dengan yang disampaikan oleh Demerouti dan Bakker (2008), bahwa tinggi rendahnya tuntutan tugas akan berdampak pada keterikatan kerja karyawan. Berkaitan dengan keterikatan, penelitian yang dilakukan Smulder (2006) kepada 4000 subjek di Netherland menunjukan salah satu profesi dengan keterikatan kerja yang rendah adalah polisi. Sementara, keterikatan kerja merupakan sesuatu hal yang penting untuk dimiliki oleh anggota polisi dalam bekerja. Sebagaimana yang dijelaskan Noerant dan Prihatsani (2018) bahwa keterikatan kerja mempunyai hubungan positif dengan berbagai hal yang berkaitan dengan organisasi dan individu.

Individu yang tidak terikat (disengaged) akan menjadi pusat masalah, kehilangan komitmen dan motivasi dalam bekerja (Aktouf, 1992), memiliki kecenderungan mengalami turnover (Schaufeli \& Bakker, 2004), memiliki sedikit tenaga dan kebahagiaan, stamina yang 
rendah dalam melakukan pekerjaan, tidak merasa bahwa pekerjaannya bermakna atau menantang, tidak menghayati pekerjaan, dan tidak merasa kesulitan untuk lepas dari pekerjaan yang dilakukan (Schaufeli \& Bakker, 2003), mengalami penurunan dalam semangat dan keterlibatan kerja, kualitas kerja, serta memiliki kontribusi yang minimal dalam pekerjaannya (Opin Enterprise Drupal, 2012). Sebaliknya, individu yang terikat (engaged) dengan pekerjaannya akan memiliki kondisi pikiran positif sehingga mampu mengekspresikan dirinya secara kognitif, fisik dan afektif dalam melakukan pekerjaan (Schaufeli \& Bakker, 2004), mampu meminimalisir terjadinya job demands yang dapat mengakibatkan burnout (Bakker \& Demerouti, 2007; Bakker, Hakanen, Demerouti, \& Xanthopoulou, 2007), melakukan pekerjaan dengan penuh semangat, berdedikasi dan larut dalam aktivitas pekerjaan, terlibat lebih banyak dalam pekerjaan, sehingga membuat mereka lebih terbuka dalam hal informasi baru dan lebih produktif (Bakker, 2011). Berdasarkan pemaparan yang telah disampaikan, memperlihatkan bahwa dampak dari terikat dan tidak terikatnya individu dengan pekerjaannya akan berpengaruh besar pada sikap ataupun perilaku individu dalam bekerja. Oleh karena itu, keterikatan kerja merupakan aspek psikologis yang penting untuk dimiliki oleh tiap anggota polisi dalam bekerja.

Berbicara tentang keterikatan kerja, Schaufeli, Salanova, Gonzalez-Roma, dan Bakker (2002), Schaufeli, Bakker, dan Salanova (2006) menjelaskan keterikatan kerja sebagai kondisi pikiran yang bersifat positif dan dipenuhi oleh hal-hal terkait dengan pekerjaan, serta ditandai dengan adanya semangat (vigor), pengabdian (dedication), dan penghayatan (absorption) pada saat individu melakukan pekerjaannya. Vigor dimaknai sebagai semangat yang tinggi saat bekerja. Dedication diartikan sebagai keterlibatan, antusiasme, serta adanya kesenangan terhadap tantangan dalam bekerja. Sementara absorption mengarah pada tingkat penghayatan yang tinggi dan keseriusan terhadap suatu pekerjaan (Gonzales-Roma, Schaufeli, Bakker \& Lloret, 2006; Schaufeli \& Bakker, 2003; 2004). Selanjutnya Shuck dan Wollard (2010) menjelaskan keterikatan kerja sebagai konstruksi yang sedikit berbeda dan unik yang terdiri dari aspek kognitif, emosional, dan perilaku individu yang berhubungan dengan peran kinerja, atau dengan kata lain diarahkan pada hasil atau pencapaian yang diinginkan organisasi.

Menurut Bakker dan Demerouti (2008), salah satu faktor yang mempengaruhi keterikatan kerja adalah personal resources. Personal resources atau yang dikenal dengan istilah sumber daya pribadi merupakan evaluasi diri secara positif yang terkait dengan ketahanan dan merujuk pada perasaan individu tentang kemampuan mengendalikan dan memberikan dampak pada lingkungan sesuai dengan keinginan dan kemampuannya. Personal resources merupakan sesuatu hal yang penting karena berasal dari dalam diri individu. Selanjutnya salah satu bentuk dari personal resources yaitu makna kerja (Wrzesniewski, 1999). Wrzesniewski dan Dutton (2001) menjelaskan bahwa makna kerja merupakan pemaknaan individu terhadap pekerjaan yang dilakukan, dan salah satu bentuk makna kerja adalah calling.

Menurut Dik dan Duffy (2009), calling merupakan panggilan transeden. Berikutnya Dik, Duffy dan Eldrige (2009) mengungkapkan bahwa istilah calling dalam konteks pekerjaan menggunakan konsep religius (menggambarkan sebuah panggilan dari Tuhan), yang mengarah pada adanya panggilan untuk setiap pekerjaan yang menciptakan rasa akan tujuan dan memberikan kebermaknaan secara pribadi atas pemenuhan nilai-nilai lain sebagai sumber motivasi utama dalam bekerja. Selanjutnya, Wrzesniewski, McCauley, Rozin, dan Schwartz (1997) menjelaskan calling sebagai pandangan individu terhadap pekerjaan sebagai sebuah panggilan. Artinya individu yang memaknai pekerjaan sebagai sebuah panggilan percaya bahwa pekerjaan yang dilakukan mampu memberikan kontribusi kepada lingkungan sosial atau pekerjaan sebagai sarana untuk melayani diri sendiri dan orang lain, dimana orientasi kerjanya ada pada pekerjaan itu sendiri. 
Dik, et al. (2009), menjelaskan beberapa dimensi dari calling, yang pertama terkait dengan pengalaman yang berasal dari luar diri, calling transendental sering dikonseptualisasikan dengan religiusitas dan spritualitas yang mempengaruhi nilai-nilai terkait dengan pekerjaan. Dimensi kedua berhubungan dengan mendekati peran hidup tertentu, dalam hal ini bertujuan untuk menunjukkan atau menghasilkan rasa dalam tujuan atau makna. Sementara dimensi ketiga dari calling adalah beriorentasi pada nilai dan tujuan, yang mana sumber utamanya merupakan motivasi. Berdasarkan hal tersebut, dapat diasumsikan bahwa anggota polisi dengan calling yang tinggi akan menemukan bahwa pekerjaan tidak dapat dipisahkan dari kehidupan dirinya. Sesuai dengan yang disampaikan Wrzesniewski, et al. (1997) bahwa individu yang memiliki calling cenderung memahami pekerjaan bukan sebagai cara mendapatkan finansial atau meningkatkan karir, melainkan untuk memenuhi panggilan yang mengantarkan mereka untuk bekerja.

Selanjutnya, bentuk lain dari personal resources menurut Lorente, Salanova, Martinez, dan Vera (2014) adalah kompetensi emosi, dan salah satu bentuk emosi adalah cinta. Selaras dengan yang diungkapkan Fredrickson (2001) bahwa salah satu kompetensi emosi yang penting adalah cinta. Cinta yang dimaksud dalam penelitian ini adalah cinta yang terkait dengan konteks pekerjaan. Hazan dan Shaver (1990) menjelaskan cinta pekerjaan sebagai kelekatan antara pekerja dengan pekerjaan yang dilakukan. Sementara Aulia, Himam, Hidayat, dan Budiarto (2019) mendeskripsikan cinta tidak hanya terkait dengan kelekatan, namun lebih mengarah pada hubungan emosi positif antara individu dengan pekerjaannya yang terjadi secara timbal balik, memiliki makna mendalam dan ditandai dengan adanya pengorbanan yang tulus ketika melakukan pekerjaan.

Penelitian yang dilakukan Wicaksono (2019) menunjukkan adanya hubungan positif antara cinta pekerjaan dengan keterikatan kerja petugas Lembaga Permasyarakatan kelas II B Sleman. Hasil penelitian tersebut menjelaskan bahwa petugas yang memiliki rasa cinta yang tinggi terhadap pekerjaannya akan menunjukkan keterikatan yang tinggi pula terhadap pekerjaannya, Petugas akan merasa senang hati menyelesaikan pekerjaan yang diberikan tanpa ada beban dalam menyelesaikan pekerjaan tersebut. Hal tersebut sesuai dengan yang diungkapkan Aulia dan Sulisworo (2018) yang menjelaskan bahwa rasa cinta individu terhadap pekerjaan akan membuat individu cenderung bersemangat dan merasa tidak memiliki beban dalam menjalani pekerjaan karena rasa terikatnya dengan pekerjaan.

Aulia (2019), Aulia, dkk. (2019) menjelaskan bahwa dimensi dari cinta pekerjaan terdiri dari kegairahan (zeal), kedekatan emosi (closeness), kesetiaan (loyality), dan ketulus-ikhlasan (heartiness). Dimensi kegairahan dalam hal ini berhubungan dengan adanya kesenangan hati, kenikmatan, penghayatan, kenyamanan, serta passion individu terhadap pekerjaannya. Dimensi kedekatan emosi berhubungan dengan kedekatan secara emosional antara individu dengan pekerjaan, serta lingkungan sosial di sekitar pekerjaan. Dimensi kesetiaan berhubungan dengan kepatuhan, komitmen dan dedikasi. Dimensi ketulus-ikhlasan diwujudkan dalam bentuk tidak berhitung tentang untung dan rugi atas apa yang diperoleh, sabar dan tidak mudah mengeluh, berbuat lebih dan cenderung memprioritaskan pekerjaan dibanding hal lain di luar pekerjaan. Oleh karena itu, dapat diasumsikan bahwa anggota polisi yang mencintai pekerjaannya akan cenderung menyelesaikan tugas dengan senang hati, memiliki kedekatan dengan pekerjaan yang dilakukan, memiliki komitmen, dan cenderung menyelesaikan pekerjaan dengan tulus ikhlas, meskipun tugas yang dikerjakan tergolong berat.

Berdasarkan fenomena dan kajian teoritis yang telah dipaparkan sebelumnya, menunjukan bahwa topik keterikatan kerja dan implikasinya terhadap individu/personal karyawan ataupun organisasi sudah banyak dibahas. Namun demikian, kajian yang berkaitan dengan faktor calling dan cinta pekerjaan baik secara bersama-sama ataupun secara parsial masih sangat kurang, khususnya dengan sampel penelitian anggota polisi. Oleh karena itu, tujuan penelitian ini adalah untuk menguji secara empiris pengaruh calling dan cinta 
pekerjaan terhadap keterikatan kerja anggota Polri, sehingga diharapkan penelitian ini dapat berkontribusi bagi pengembangan keilmuan, khususnya dalam konteks bidang psikologi polisi yang baru mulai marak dikaji di Indonesia.

\section{Metode}

Penelitian ini menggunakan metode kuantitatif dengan desain crossectional study. Populasi pada penelitian ini adalah anggota polisi yang masih aktif bekerja dan memiliki masa kerja minimal satu tahun. Pengambilan sampel dilakukan dengan teknik purposive sampling. Purposive sampling merupakan teknik pengambilan sampel penelitian dengan beberapa pertimbangan tertentu yang bertujuan agar data yang diperoleh lebih representatif. Oleh karena itu, untuk memenuhi karakteristik sampling yang purposive, maka penelitian ini menggunakan sampel anggota polisi dengan masa kerja minimal satu tahun dan sedang bertugas aktif di Polda Metro Jaya. Alasan peneliti menggunakan Polda Metro Jaya sebagai sampel penelitian dikarenakan Polda Metro Jaya merupakan satu-satunya Polda di Indonesia yang memiliki status A+. Oleh karena itu, pemilihan sampel pada anggota polisi di Polda Metro Jaya diasumsikan mampu merepresentasikan kondisi dari anggota Polisi secara umum yang ada di seluruh wilayah Indonesia. Total sampel pada penelitian ini adalah sebanyak 430 anggota polisi. Sebelum pengambilan data dilakukan, sampel diminta untuk mengisi lembar kesediaan (informed consent) untuk menjadi bagian dari penelitian.

Metode pengambilan data dalam penelitian ini menggunakan tiga alat ukur, yaitu UWES modifikasi, skala calling dan skala cinta pekerjaan. Variabel keterikatan kerja diukur dengan mengadopsi Utrecht Work Engagement Scale (UWES) yang telah dimodifikasi oleh Aulia (2018) dari Schaufeli dan Bakker (2003). UWES yang telah dimodifikasi menjadi 18 aitem memiliki koefisien validitas butir aitem bergerak dari $V=0,611$ hingga $V=0,889$ (Aulia, 2018; Aulia, dkk., 2019). Selanjutnya koefisien validitas UWES modifikasi adalah sebesar V=0,76, yang dapat dimaknai bahwa UWES yang telah dimodifikasi Aulia (2018) memiliki validitas yang tergolong tinggi (valid). Koefisien reliabilitas Alpha Cronbach dari UWES modifikasi yang telah diuji pada sampel tentara (Aulia, 2018) menunjukan koefisien reliabilitas yang tinggi yaitu sebesar $r_{x x}=0,898$. Selanjutnya pada penelitian ini, UWES modifikasi Aulia (2018) dilakukan pengujian reliabilitas kembali, yaitu dengan menggunakan sampel anggota Polisi di Polda Metro Jaya. Adapun hasil perolehan koefisien reliabilitas UWES modifikasi tersebut menunjukan koefisien reliabilitas tergolong tinggi (reliabel), yaitu sebesar $r_{x x^{\prime}}=0,850$.

Variabel calling pada penelitian ini diukur dengan melakukan modifikasi dari skala calling yang telah disusun oleh Taza (2018) berdasarkan dimensi calling dari Dik, et al. (2009). Skala calling yang terdiri dari 12 aitem pada penelitian ini diuji dengan menggunakan validitas isi melalui professional judgment (rater). Adapun hasil penilaian dari rater selanjutnya dianalisis dengan menggunakan formula Aiken's dan memperoleh validitas butir aitem bergerak dari $\mathrm{V}=0,75$ hingga $\mathrm{V}=0,95$. Sementara koefisien validitas skala calling adalah sebesar $\mathrm{V}=0,88$. Berdasarkan perolehan tersebut maka dapat dimakanai bahwa skala calling memiliki koefisien validitas yang tergolong tinggi (valid). Selanjutnya pengujian reliabilitas skala calling dilakukan kepada sampel anggota Polisi Polda Metro Jaya. Adapun perolehan koefisien reliabilitas dari hasil pengujian tergolong tinggi (reliabel), yaitu sebesar $r_{x x^{\prime}}=0,895$.

Variabel cinta pekerjaan pada penelitian ini diukur menggunakan skala cinta pekerjaan yang disusun oleh peneliti berdasarkan dimensi cinta pekerjaan dari Aulia (2019), dan Aulia, dkk. (2019). Skala cinta pekerjaan yang terdiri dari 20 aitem pada penelitian ini diuji dengan menggunakan validitas isi melalui professional judgment (rater). Adapun hasil penilaian dari rater selanjutnya dianalisis dengan menggunakan formula Aiken's dan memperoleh validitas butir aitem bergerak dari $V=0,675$ hingga $V=0,925$. Sementara koefisien validitas skala cinta pekerjaan juga tergolong tinggi (valid) yaitu sebesar $V=0,814$. Selanjutnya koefisien reliabilitas skala cinta pekerjaan pada penelitian ini tergolong tinggi (reliabel), yaitu sebesar 
$\mathrm{r}_{\mathrm{xx}}=0,919$.

Berdasarkan perolehan koefisien validitas dan reliabilitas dari ketiga alat ukur yang telah disampaikan sebelumnya, maka dapat dikatakan bahwa alat pengumpulan data pada penelitian ini valid dan reliabel, sehingga ketiga alat ukur dapat digunakan di dalam penelitian. Selanjutnya, teknik analisis data yang digunakan dalam rangka menguji hipotesis pada penelitian ini adalah teknik analisis regresi linear berganda.

\section{Hasil}

Sebelum dilakukan uji dengan analisis regresi berganda, terlebih dahulu peneliti melakukan uji asumsi, diantaranya uji normalitas dan multikolinieritas. Hasil uji normalitas dengan menggunakan nilai residual menunjukan perolehan nilai $p=0,200(p>0,05)$, artinya variasi dari skor sampel terdistribusi secara normal. Sementara hasil uji multikolinieritas memperlihatkan nilai VIF antara variabel calling dan cinta pekerjaan adalah sebesar $\mathrm{VIF}=1,781$ (VIF< 10$)$, artinya tidak terjadi multikolinieritas atau dengan kata lain tidak ada hubungan antar variabel bebas yang diteliti. Berikutnya, berdasarkan hasil uji asumsi yang telah dilakukan, maka teknik analisis data dengan menggunakan regresi linier berganda dapat dilanjutkan.

Hasil analisis regresi linier berganda dengan menggunakan 430 anggota polisi dari Polda Metro Jaya menunjukan perolehan koefisien nilai regresi adalah sebesar $\mathrm{R}=0,644$, dan $\mathrm{F}=151,449, \mathrm{p}=0,000(\mathrm{p}<0,001)$, seperti pada tabel 1. Hasil perolehan tersebut menjelaskan bahwa secara simultan calling dan cinta pekerjaan memiliki pengaruh yang sangat signifikan terhadap keterikatan kerja anggota polisi. Hasil analisis juga menjelaskan bahwa sumbangan efektif dari calling dan cinta pekerjaan terhadap keterikatan kerja adalah sebesar 41,5\%.

Tabel 1.

Hasil Analisis Regresi Berganda

\begin{tabular}{lllll}
\hline Variabel & $\boldsymbol{R}$ & $\boldsymbol{F}$ & $\boldsymbol{R}^{\mathbf{2}}$ & Sig. \\
\hline Calling \& Cinta Pekerjaan*Keterikatan Kerja & 0,644 & 151,449 & 0,415 & 0,000 \\
\hline
\end{tabular}

Hasil uji regresi sederhana pada tabel 2 mengungkapkan calling memiliki pengaruh yang sangat signifikan terhadap keterikatan kerja anggota polisi. Hal tersebut ditunjukan melalui perolehan koefisien nilai $\beta=0,248$ dan $t=5,028$ dengan $p=0,000(p<0,01)$. Selanjutnya hasil uji regresi juga menjelaskan bahwa cinta pekerjaan memiliki pengaruh yang sangat sigifikan terhadap keterikatan kerja anggota polisi. Hal tersebut seperti yang terlihat pada tabel 2 dimana koefisien nilai $\beta=0,452$ dan $t=9,156$ dengan $p=0,000(p<0,01)$.

Tabel 2.

Hasil Uji Analisis Masing-masing Pasangan

\begin{tabular}{llll}
\hline Variabel & $\boldsymbol{\beta}$ & $\boldsymbol{t}$ & $\boldsymbol{S}$ Sig. \\
\hline Calling*Keterikatan Kerja & 0,248 & 5,028 & 0,000 \\
Cinta Pekerjaan*Keterikatan Kerja & 0,452 & 9,156 & 0,000 \\
\hline
\end{tabular}

Berdasarkan kategorisasi dengan menggunakan mean hipotetik dari 430 sampel penelitian menunjukan bahwa secara dominan yaitu sebanyak $94,9 \%$ anggota polisi Polda Metro Jaya memiliki calling yang tinggi, dan selebihnya yaitu sebanyak 5,1\% memiliki calling pada kategori sedang. Selanjutnya sebanyak $85,3 \%$ anggota polisi memiliki rasa cinta yang tinggi terhadap pekerjaan, dan hanya sebanyak $14,7 \%$ memiliki rasa cinta pada kategori sedang terhadap pekerjaan. Selain itu, sebanyak $66,7 \%$ anggota polisi memiliki keterikatan yang tinggi terhadap pekerjaan, sebanyak 33\% memiliki keterikatan kerja pada kaegori sedang, dan hanya sebanyak $0,2 \%$ anggota polisi memiliki keterikatan kerja yang rendah. Secara lengkap kategorisasi masing-masing variabel dapat dilihat pada tabel 3. 
Tabel 3.

Kategorisasi Sampel Penelitian Berdasarkan Mean Hipotetik

\begin{tabular}{llll}
\hline Variabel & Kategori & Jumlah & \% \\
\hline Calling & Tinggi & 408 & 94,9 \\
& Sedang & 22 & 5,1 \\
& Rendah & 0 & 0 \\
\hline Cinta Pekerjaan & Besar & 367 & 85,3 \\
& Cukup & 63 & 14,7 \\
& Kecil & 0 & 0 \\
\hline Keterikatan Kerja & Terikat aktif & 287 & 66,7 \\
& Terikat & 142 & 33 \\
& Tidak terikat & 1 & 0,2 \\
\hline
\end{tabular}

\section{Pembahasan}

Hasil analisis regresi menunjukan bahwa secara simultan calling dan cinta pekerjaan memiliki pengaruh terhadap keterikatan kerja anggota polisi. Artinya calling dan cinta pekerjaan secara bersama-sama mampu menjadi prediktor untuk memprediksi tinggi ataupun rendahnya keterikatan kerja yang dimiliki anggota polisi, khususnya yang bertugas di Polda Metro Jaya. Hal tersebut diiringi dengan sumbangan efektif yang tergolong tinggi dari calling dan cinta pekerjaan terhadap keterikatan kerja, yaitu sebesar 41,5\%. Hasil penelitian ini menjelaskan bahwa calling yang tinggi dan diiringi dengan rasa cinta yang besar dari anggota terhadap pekerjaan mampu membuat anggota polisi lebih terikat secara aktif terhadap pekerjaan yang dilakukannya. Sebaliknya, calling yang rendah dan diiringi dengan kecilnya rasa cinta yang dimiliki anggota terhadap pekerjaan juga mampu membuat anggota polisi tidak terikat dengan pekerjaan yang dilakukan. Artinya, terikat atau tidaknya anggota polisi terhadap pekerjaan yang dilakukan tergantung dari tinggi atau rendahnya calling dan besar atau kecilnya rasa cinta yang dimiliki anggota polisi terhadap pekerjaan yang dilakukan.

Secara parsial, temuan penelitian ini menunjukan bahwa calling mempengaruhi keterikatan kerja anggota polisi. Hal tersebut menjelaskan bahwa anggota polisi dengan calling yang tinggi akan merasa bersemangat, memiliki harga diri atas identitas sebagai seorang polisi, serta mampu menghayati pekerjaan yang dilakukan secara kuat. Perasaan kuat yang dimiliki akan membuat anggota polisi mampu mengerahkan energi yang besar ke dalam pekerjaan dan membuat anggota cenderung tidak menarik diri dari pekerjaan, meskipun tuntutan tugas dan resiko pekerjaan yang dihadapi tergolong tinggi. Hal tersebut sesuai dengan temuan penelitian yang menunjukan bahwa dari 430 anggota polisi yang menjadi sampel penelitian, sebanyak 5,1\% memiliki calling pada kategori sedang, sementara sebanyak $94,9 \%$ anggota polisi memiliki calling yang tinggi terhadap pekerjaan mereka, dan hal tersebut berpimplikasi pada keterikatan kerja anggota polisi, dimana sebanyak 33\% telah terikat dengan pekerjaan yang dilakukan, bahkan sebanyak $66,7 \%$ terikat secara aktif dengan pekerjaan yang dilakukan.

Temuan penelitian ini juga menjelaskan bahwa calling merupakan sumber daya pribadi yang penting bagi keterikatan kerja anggota polisi. Temuan penelitian ini sesuai dengan yang disampaikan Cao, Liu, J., Liu, K., Yang, dan Liu, Y. (2019) bahwa calling merupakan sumber daya pribadi dan faktor motivasi yang penting, meskipun lingkungan kerja tergolong berat, namun individu yang memiliki calling akan rela menghadapi berbagai tantangan dan kesulitan, bahkan berkorban untuk hal tersebut. Hasil penelitian ini juga telah mengkonfirmasi penelitian yang telah dilakukan oleh para peneliti sebelumnya, baik di Indonesia ataupun di luar negeri yang menjelaskan adanya hubungan positif antara calling dengan keterikatan kerja (Ramdhani, 2008; Hirschi, 2012 ; Goran, 2016 ; Tanudjaja, 2013; 
Ziedelis, 2018 ; Cao, et al., 2019).

Adanya pengaruh calling terhadap keterikatan kerja anggota kepolisian pada penelitian ini sesuai dengan yang disampaikan Wrzesniewski, et al. (1997), bahwa individu yang memiliki calling, memahami pekerjaan mereka bukan untuk finansial atau menaikkan karir, melainkan untuk memenuhi panggilan yang membawa mereka bekerja. Hal tersebut sesuai dengan penelitian yang dilakukan oleh Tanudjaja (2013) bahwa individu dengan makna kerja sebagai calling tidak lagi menganggap bahwa pekerjaan sebagai alat untuk memenuhi kebutuhan hidup, namun untuk memegang filosofi tujuan dari pekerjaan tersebut. Begitupula Ramdhani (2008) menjelaskan bahwa seorang pekerja dengan calling yang tinggi adalah mereka yang memberikan pelayanan sesuai dengan tugasnya. Sementara, pekerja dengan calling yang rendah cenderung mengabaikan standar pekerjaan, enggan bekerja keras, tidak semangat, lebih suka bersantai bahkan cenderung mengabaikan pekerjaan. Dengan demikian, hal tersebut dapat berdampak pada rendahnya keterikatan kerja yang dimiliki individu.

Hasil penelitian ini secara parsial juga menunjukan bahwa cinta pekerjaan memengaruhi keterikatan kerja anggota polisi. Dengan demikian temuan penelitian ini menjelaskan bahwa anggota polisi yang memiliki rasa cinta yang besar terhadap pekerjaan akan merasa sangat bergairah, merasa dekat dengan pekerjaan dan lingkungan kerja, memiliki kesetiaan, dan rela melakukan secara tulus ikhlas tanpa berharap imbalan apapun atas pekerjaan yang mereka lakukan. Implikasi dari rasa cinta yang besar terhadap pekerjaan membuat anggota polisi tetap merasa nyaman dan terikat dengan pekerjaan yang dilakukan, meski tuntutan tugas ataupun beban kerja yang mereka lakukan tergolong tinggi. Hal tersebut dapat dilihat dari hasil temuan yang juga menunjukan sebanyak $14,7 \%$ anggota polisi memiliki rasa cinta terhadap pekerjaan yang dilakukan, bahkan sebanyak $85,3 \%$ memiliki cinta yang besar terhadap pekerjaan yang mereka lakukan. Rasa cinta tersebut juga berpimplikasi pada keterikatan kerja anggota polisi, dimana dari temuan penelitian ini mendeskripsikan sebanyak 33\% anggota polisi telah terikat dengan pekerjaan yang dilakukan, bahkan sebanyak $66,7 \%$ terikat secara aktif dengan pekerjaan yang dilakukan.

Temuan penelitian ini menjelaskan bahwa cinta pekerjaan merupakan sumber daya pribadi yang berkontribusi besar terhadap keterikatan kerja anggota polisi. Hasil temuan saat ini mengkonfirmasi temuan dari penelitian sebelumnya yang menjelaskan bahwa banyak individu yang terikat/terlibat lebih dalam pada pekerjaan dikarenakan cinta (Arnett, 2000; Osgood, Ruth, Eccles, Jacob dan Barber, 2005; Shulman dan Nurmi, 2010). Hal tersebut sesuai dengan yang disampaikan Aulia, dkk. (2019) bahwa cinta pekerjaan merupakan sesuatu hal yang penting dalam bekerja karena mampu meningkatkan keterikatan individu dengan pekerjaan yang mereka lakukan. Temuan penelitian ini juga telah mengkonfirmasi yang disampaikan Aulia dan Sulisworo (2018), bahwa individu yang memiliki rasa cinta terhadap pekerjaan, tidak akan melihat untung rugi dari yang dikerjakannya. Selain itu, individu akan memberikan yang terbaik dari kemampuan yang dimiliki karena rasa terikatnya pada pekerjaan. Sesuai dengan yang dijelaskan oleh Bygrave (2011) bahwa rasa cinta karyawan terhadap pekerjaan mampu memprediksi kesejahteraan dan memberikan semangat pada karyawan untuk terus bekerja. Adanya rasa cinta dari karyawan terhadap pekerjaan membuat mereka cenderung bersemangat dan merasa tidak memiliki beban dalam menjalani pekerjaan. Oleh karena itu, hasil penelitian ini semakin memberi penguatan secara empirik bahwa cinta pekerjaan memiliki pengaruh yang besar terhadap terikatnya anggota polisi dengan pekerjaan yang dilakukannya.

Berdasarkan hasil penelitian ini, dapat dijelaskan bahwa ada sebesar 58,5\% faktor lain di luar calling dan cinta pekerjaan yang dapat mempengaruhi keterikatan kerja anggota polisi. Faktor lain yang diasumsikan dapat mempengaruhi keterikatan kerja anggota polisi dapat berasal dari dalam ataupun dari luar diri anggota polisi. Dengan demikian, hal tersebut merupakan peluang untuk para peneliti selanjutnya yang tertarik mengkaji lebih dalam berkaitan dengan keterikatan kerja anggota kepolisian. 
Secara umum, penelitian ini masih sangat jauh dari kata sempurna. Adapun kelemahan penelitian ini adalah berkaitan dengan jumlah partisipan yang terbatas, sehingga generalisasi hasil penelitian ini terbatas hanya pada sampel penelitian dan belum dapat digeneralisasikan pada populasi yang lebih luas. Selain itu, mengingat desain penelitian yang digunakan tidak bersifat longitudinal sehingga potensi untuk terjadinya perbedaan antara hasil penelitian saat ini dengan hasil penelitian di masa yang akan datang masih sangat besar. Oleh sebab itu, mengingat beberapa keterbatasan pada penelitian ini, maka untuk para peneliti selanjutnya yang akan melakukan penelitian berkaitan dengan keterikatan kerja khususnya dalam lingkup Polri, dapat mengkaitkan keterikatan kerja dengan variabel bebas dan pendekatan lainnya, sehingga hasil kajian akan dapat lebih memperkaya pengembangan ilmu dan berkontribusi besar khususnya pada bidang kajian psikologi polisi.

\section{Simpulan}

Berdasarkan hasil penelitian yang telah diuraikan sebelumnya, menunjukan bahwa tingginya tuntutan tugas dan resiko pekerjaan yang diemban oleh anggota Polisi Republik Indonesia (Polri), khususnya yang bertugas di Polda Metro Jaya tidak berdampak pada rendahnya keterikatan kerja anggota. Hal tersebut dikarenakan hasil penelitian menunjukan bahwa anggota Polri secara dominan terikat aktif (actively engaged) dengan pekerjaannya. Dengan demikian, hasil penelitian ini menyimpulkan bahwa anggota Polri, khususnya yang bertugas di Polda Metro Jaya memiliki keterikatan kerja yang tinggi. Tingginya keterikatan kerja anggota Polri pada penelitian ini menunjukan adanya perbedaan dengan kondisi keterikatan kerja anggota polisi di Netherland yang tergolong rendah berdasarkan hasil penelitian yang dilakukan oleh Smulder (2006). Selanjutnya, dapat disimpulkan bahwa tingginya keterikatan kerja anggota Polri pada penelitian ini dipengaruhi oleh calling dan cinta pekerjaan yang dimiliki oleh anggota. Hal tersebut dikarenakan hasil penelitian menunjukan bahwa secara bersama-sama (simultan) dan secara terpisah (parsial) calling dan cinta pekerjaan mempengaruhi keterikatan kerja anggota Polri.

\section{DAFTAR PUSTAKA}

Aktouf, 0. (1992). Management and theories of organizations in the 1990s: Toward a critical radical humanism. Academy of Management Review, 17, 407-431.

Arnett, J. J. (2000). Emerging adulthood: A theory of development from the late teens through the twenties. American psychologist, 55(5), 469.

Aulia, A. (2018). Keterikatan kerja ditinjau dari cinta pekerjaan, efikasi diri, dan persepsi dukungan organisasi. Tesis. Universitas Ahmad Dahlan: Yogyakarta.

Aulia. (2019). Berkorban demi Ibu Pertiwi: Esensi dan dinamika cinta pekerjaan pada Pasukan Elit Indonesia. Disertasi. Program Doktor Ilmu Psikologi Universitas Gadjah Mada: Yogyakarta.

Aulia, Z. A. I., \& Sulisworo, D. (2018). A study on the role of love to in the character building of Army soldiers in Indonesia. International Journal of Research, 7(1), 13-19. https://doi.org/10.5861/ijrsp.2017.2004.

Aulia, A., Sutanto, A., \& Hidayat, A. C. (2019). Determinants of work engagement for TNI-AD (Indonesian Armed Forces-Army) personnel [Determinan keterikatan kerja personel Tentara Nasional Indonesia-Angkatan Darat (TNI-AD)].ANIMA Indonesian Psychological Journal, 35(1), 35-55. https://doi.org/10.24123/aipj.v35i1.2881.

Aulia, A., Himam, F., Hidayat, R., \& Budiarto, A. (2019). Fake love or true love? Sacrificial love as the essence of love of work phenomenon in Indonesian Elite Forces. Journal of Educational, Health and Community Psychology, 8(3), 215-238. http://dx.doi.org/10.12928/jehcp.v8i3.13830. 
Bakker, A. B. (2011). An evidence-based model of work engagement. Current directions in psychological science, 20(4), 265-269. https://doi.org/10.1177/0963721411414534.

Bakker, A. B., \& Demerouti, E. (2007). The job demands-resources model: State of the art. Journal of managerial psychology, 22(3), 309-328. https://doi.org/10.1108/02683940710733115.

Bakker, A. B., \& Demerouti, E. (2008). Towards a model of work engagement. Career development international, 209-223. https://doi.org/10.1108/13620430810870476.

Bakker, A. B., Hakanen, J. J., Demerouti, E., \& Xanthopoulou, D. (2007). Job resources boost work engagement, particularly when job demands are high. Journal of educational psychology, 99(2), 274. https://doi.org/10.1037/0022-0663.99.2.274.

Bygrave, C. E. (2011). The power of love: An examination of the measures, antecedents, and outcomes of love of the job. Thesis. Canada: Submitted to Saint Mary's University, Halifax, Nova Scotia in Partial Fulfillment of the Requirements for the Degree of Doctor of Philosophy in Business Administration.

Cao, Y., Liu, J., Liu, K., Yang, M., \& Liu, Y. (2019). The mediating role of organizational commitment between calling and work engagement of nurses: A cross-sectional study. International journal of nursing sciences, 6(3), 309-314. https://doi.org/10.1016/j.ijnss.2019.05.004.

Demerouti, E., \& Bakker, A. B. (2008). The Oldenburg Burnout Inventory: A good alternative to measure burnout and engagement. Handbook of stress and burnout in health care, 65, 78.

Dik, B. J., \& Duffy, R. D. (2009). Calling and vocation at work: Definitions and prospects for research and practice. The counseling psychologist,37(3), 424-450. https://doi.org/10.1177/0011000008316430.

Dik, B. J., Duffy, R. D., \& Eldridge, B. M. (2009). Calling and vocation in career counseling: Recommendations for promoting meaningful work. Professional Psychology: Research and Practice, 40(6), 625. https://doi.org/10.1037/a0015547.

Fredrickson, B. L. (2001). The role of positive emotions in positive psychology: the broadenand-build theory of positive emotions. American psychologist, 56(3), 218. https://doi.org/10.1037/0003-066X.56.3.218.

Gonzales-Roma, V., Schaufeli, B. W., Bakker, A. B., \& Lloret, S. (2006). Burnout and work engagement: Independent factors or opposite poles? Journal of Vocational Behavior, 68, 165-174. https://doi.org/10.1016/j.jvb.2005.01.003.

Goran, O. S. S. (2016). Hubungan makna kerja panggilan dengan keterikatan kerja pada penyiar radio di Surabaya. Universitas Surabaya, Magister Sains Psikologi. Seminar Nasional dan Gelar Produk. SENASPRO 2016.

Guntur, M. (2017). Fungsi kepolisian negara dalam pemeliharaan keamanan dan ketertiban pada masyarakat Kota Sengkang Kabupaten Wajo. Al-Hikam, 1(3), 64-78.

Hazan, C., \& Shaver, P. R. (1990). Love and work: An attachment-theoretical perspective. Journal of Personality and social Psychology, 59(2), 270.

Hirschi, A. (2012). Callings and work engagement: Moderated mediation model of work meaningfulness, occupational identity, and occupational self-efficacy. Journal of Counseling Psychology, 59(3), 479-485. https://doi.org/10.1037/a0028949.

Lorente, L., Salanova, M., Martínez, I. M., \& Vera, M. (2014). How personal resources predict work engagement and self-rated performance among construction workers: A social cognitive perspective. International Journal of Psychology,49(3), 200-207. https://doi.org/10.1002/ijop.12049.

Noerant, S. 0., \& Prihatsani, U. (2018). Hubungan antara iklim organisasi dengan work engagement pada anggota Sabhara Polda Jateng Semarang. Empati, 6 (4), 354-361. 
Opin Enterprise Drupal. (2012). Engage vs disenageged employee. https://www.opin.ca/en/article/engaged-vs-disengaged-employees.

Osgood, D.W., Ruth, G., Eccles, J.S., Jacobs, J.E., \& Barber, B.L. (2005). Six paths to adulthood. In R.A. Settersten, Jr., F.F. Furstenberg, \& R.G. Rumbaut (Eds.), On the frontier of adulthood. Theory, research and public policy (pp. 320-355). Chicago: The University of Chicago Press.

Ramdhani, J. (2008). Motivation and perceived productivity at a merged higher education institution (Doctoral dissertation). Durban University of Technology in the Faculty of Commerce. https://openscholar.dut.ac.za/bitstream/10321/422/4/Ramdhani_2008.pdf.

Schaufeli, W. B., \& Bakker, A. B. (2003). Utrecht work engagement scale: preliminary manual. Department of Psychology. The Netherlands: Utrecht University.

Schaufeli, W.B. and Bakker, A.B. (2004), "Job demands, job resources, and their relationship with burnout and engagement: a multi-sample study", Journal of Organizational Behavior, Vol. 25, pp. 293-315. https://doi.org/10.1002/job.248.

Schaufeli, W. B., Bakker, A. B., \& Salanova, M. (2006). The measurement of work engagement with a short questionnaire: A cross-national study. Educational and psychological measurement, 66(4), 701-716. https://doi.org/10.1177/0013164405282471.

Schaufeli, W.B., Salanova, M., González-romá, V. et al. The measurement of engagement and burnout: A two sample confirmatory factor analytic approach. Journal of Happiness Studies 3, 71-92 (2002). https://doi.org/10.1023/A:1015630930326.

Shuck, B., \& Wollard, K. (2010). Employee engagement and HRD: A seminal review of the foundations. Human resource development review, 9(1), 89-110. https://doi.org/10.1177/1534484309353560.

Shulman, S., \& Nurmi, J. E. (2010). Understanding emerging adulthood from a goal-setting perspective. New directions for child and adolescent development, 2010(130), 1-11. https://doi.org/10.1002/cd.277.

Smulders, P. (2006). Assessing employee's work engagement. Hoofddorp: TNO-special september.

Tanudjaja, R. M. (2013). Hubungan antara konflik keluarga-kerja, makna kerja sebagai panggilan, dan persepsi terhadap dukungan organisasional dengan keterikatan kerja pada guru. Calyptra, 2(1), 1-10.

Taza, Alle. (2018). Hubungan antara makna kerja panggilan kerja dengan keterikatan kerja pada prajurit TNI. Skripsi Psikologi Yogyakarta: Universitas Ahmad Dahlan Yogyakarta: Universitas Ahmad Dahlan.

Wicaksono, A. E. (2019). Hubungan antara cinta pekerjaan dan psychological well-being dengan work engagement pada petugas lembaga permasyarakatan kelas II B Sleman. Skripsi. Universitas Ahmad Dahlan: Yogyakarta.

Wrzesniewski, A. E. (1999). Jobs, careers, and callings: Work orientation and job transitions. University of Michigan.

Wrzesniewski, A., \& Dutton, J. E. (2001). Crafting a job: Revisioning employees as active crafters of their work. Academy of management review,26(2), 179-201. https://doi.org/10.5465/amr.2001.4378011.

Wrzesniewski, A., McCauley, C., Rozin, P., \& Schwartz, B. (1997). Jobs, careers, and callings: People's relations to their work. Journal of research in personality,31(1), 21-33. https://doi.org/10.1006/jrpe.1997.2162.

Ziedelis, A. (2019). Perceived calling and work engagement among nurses. Western journal of nursing research, 41(6), 816-833.https://doi.org/10.1177/0193945918767631. 


\section{LAMPIRAN A}

\section{Utrecht Work Engagement Scale Modifikasi}

\section{PETUNJUK “WE"}

- Dari 18 pernyataan berikut ini adalah hal yang anda rasakan saat bekerja. Bacalah setiap pernyataan secara hati-hati dan silahkan tulis sesuai dengan yang anda rasakan tentang pekerjaan anda. Jika anda merasakan, indikasi (tidak pernah-sering), silahkan menuliskan angka (dari 0-4) yang menggambarkan seberapa kerap anda merasakan hal tersebut

\begin{tabular}{|c|c|c|c|c|}
\hline TIDAK PERNAH & JARANG & KADANG-KADANG & SERING & SELALU \\
\hline $\mathbf{0}$ & $\mathbf{1}$ & $\mathbf{2}$ & $\mathbf{3}$ & $\mathbf{4}$ \\
\hline
\end{tabular}

Di tempat kerja, saya merasa penuh dengan energi (VI1)

3. Saya memandang pekerjaan yang dilakukan penuh dengan makna (DE1)

Waktu terasa begitu cepat ketika saya bekerja (AB1)

4. _ _ Pada saat bekerja, saya merasa kuat dan penuh semangat (VI2)

5. — _ Saya antusias dengan pekerjaan yang dilakukan (DE2)

6. ـ _ Saat bekerja, saya seakan lupa hal lain yang ada di sekitar (AB2)

7. —— Pekerjaan ini menginspirasi saya (DE3)

8. __ Saat bangun di pagi hari, saya merasa seperti akan pergi bekerja (VI3)

9. __ Saya merasa senang ketika bekerja secara terus menerus (AB3)

$10 . \quad$ Saya bangga pada pekerjaan ini (DE4)

11. __ Saya terlena dengan pekerjaan ini (AB4)

12. __ Saya bisa terus bekerja untuk waktu yang sangat lama (VI4)

13. —— Bagi saya, pekerjaan ini menantang (DE5)

14. _— Saya menikmati pekerjaan ini (AB5)

15. __ Saya merasa sangat tangguh secara mental dengan pekerjaan ini (VI5)

16. __ Saya merasa tidak dapat melepaskan diri dari pekerjaan ini (AB6)

17. __ saya tetap bertahan di tempat kerja, bahkan ketika sesuatu terjadi di luar kehendak saya (VI6)

18. Pada saat libur, saya merindukan pekerjaan ini (DE6) 


\section{LAMPIRAN B}

\section{Skala Cinta Pekerjaan}

\section{PETUNJUK "LoW"}

- Dari 20 pernyataan berikut ini adalah hal yang anda rasakan terhadap pekerjaan anda. Bacalah setiap pernyataan secara hati-hati dan silahkan tulis sesuai dengan yang anda rasakan tentang pekerjaan anda. Jika anda merasakan, indikasi (tidak pernah-sering), silahkan menuliskan angka (dari 0-4) yang menggambarkan seberapa kerap anda merasakan hal tersebut terhadap pekerjaan anda

\begin{tabular}{|c|c|c|c|c|}
\hline TIDAK PERNAH & JARANG & KADANG-KADANG & SERING & SELALU \\
\hline $\mathbf{0}$ & $\mathbf{1}$ & $\mathbf{2}$ & $\mathbf{3}$ & $\mathbf{4}$ \\
\hline
\end{tabular}

Saya melakukan pekerjaan dengan senang hati (Z1)

2. __ Pekerjaan ini sudah menjadi bagian dari hidup saya (C1)

3. _ Saya patuh terhadap semua aturan yang ada di kantor (L1)

4. __ Saya tidak berhitung untung dan rugi atas apa yang telah dilakukan $(\mathrm{H} 1)$

5. _ _ Saya menikmati tiap hal yang dikerjakan (Z2)

6. _ Pada saat libur, saya senantiasa merindukan teman-teman kantor (C2)

$7 . \quad$ Salah satu bentuk ketaatan saya adalah senantiasa siap menjalankan tugas (L2)

8. _ Saya tidak pernah mengeluh saat bekerja $(\mathrm{H} 2)$

9. __ Saya mengerjakan tugas dengan penuh penghayatan (Z3)

10. _ Saya merasa hampa saat tidak bekerja (C3)

11. __ Saya mengerjakan sesuatu sesuai dengan yang diucapkan (L3)

12. _ Meski pekerjaan ini sulit, namun saya tetap sabar mengerjakannya (H3)

13. __ Saya melaksanakan pekerjaan dengan perasaan nyaman (Z4)

14. __ Saya merasa tidak dapat jauh dari pekerjaan yang biasa dilakukan (C4)

15. Tidak pernah terlintas keinginan untuk meninggalkan pekerjaan ini (L4)

16. __ Saya memberikan yang terbaik dari yang dimiliki untuk pekerjaan $(\mathrm{H} 4)$

17. _ Pekerjaan ini sudah sesuai dengan passion saya (Z5)

18. __ Saya merasa senasib sepenanggungan dengan rekan di lingkungan kerja (C5)

19. _ Saya rela berkorban jiwa dan raga untuk pekerjaan (L5)

20. __ Saya tulus memprioritaskan pekerjaan dibandingkan hal lainnya (H5) 


\section{LAMPIRAN C}

\section{Skala Calling}

\section{PETUNJUK "CALL"}

- Dari 12 pernyataan berikut ini adalah hal yang anda rasakan pada tentang pekerjaan anda. Bacalah setiap pernyataan secara hati-hati dan silahkan tulis sesuai dengan yang anda rasakan tentang pekerjaan anda. Indikasikan seberapa sesuai hal tersebut anda rasakan dengan cara menuliskan angka (dari 0-4) dalam merasakan hal tersebut

\begin{tabular}{|c|c|c|c|c|}
\hline SANGAT TIDAK SESUAI & TIDAK SESUAI & NETRAL & SESUAI & SANGAT SESUAI \\
\hline 0 & 1 & 2 & 3 & 4 \\
\hline
\end{tabular}

\footnotetext{
1. ___ Nilai religius yang diajarkan oleh agama membuat saya melakukan pekerjaan ini (PL1)

2. __ Dengan menjadi polisi, saya merasa hidup ini lebih bermakna (PH1)

3. ___ Pekerjaan ini saya lakukan sebagai bentuk rasa syukur kepada Tuhan (NT1)

4. ___ Nilai-nilai agama mendorong saya untuk melakukan pekerjaan dengan benar (PL2)

5. __ Menjadi polisi adalah salah satu cara saya untuk mengabdi pada Tuhan ( $\mathrm{PH} 2)$

6. __ Saya melakukan pekerjaan ini karena ingin memiliki arti dalam hidup (NT2)

7. __ _ _ Saya melakukan pekerjaan sesuai dengan nilai-nilai yang ada pada ajaran agama (PL3)

8. __ _ _ Bekerja sebagai polisi memberikan arti tersendiri bagi hidup saya ( $\mathrm{PH} 3$ )

9. __ _ _ Pekerjaan ini saya lakukan agar dapat bermanfaat bagi masyarakat (NT3)

10. __ Dorongan dari luar mempengaruhi spiritualitas saya sehingga merasa harus melakukan pekerjaan ini (PL4)

11. __ Menjadi polisi adalah suatu kebanggaan bagi diri saya (PH4)

12. ___ Saya mendapatkan kebahagiaan dalam menjalani tugas sebagai polisi (NT4)
} 